\title{
Growth Velocity and Plasma Amino Acids in the Newborn
}

\author{
P. H. SCOTT, H. M. BERGER, ${ }^{1}$ AND B. A. WHARTON \\ Biochemistry Department, Selly Oak Hospital and Sorrento Maternity Hospital, Birmingham, England
}

\begin{abstract}
Plasma amino acid levels in newborn babies are often measured as part of a screening for inherited metabolic disease, or less commonly as part of a nutritional assessment. We have examined certain factors which affect the levels as measured in low birth weight babies during the first 3 wk of life. As in other studies, plasma amino acid concentrations were shown to fall with increasing gestational and postnatal age, and to reflect to some extent the amino acid composition of the dietary protein. In addition, however, plasma branched-chain amino acids and cystine were found to be inversely related to growth velocity and nitrogen retention. These results could be interpreted to suggest that some low birth weight babies were malnourished. However accompanying anthropometric and clinical data showed that these particular babies were healthy and growing rapidly; they were unlikely to be truly malnourished. Rather we suggest they were experiencing "protein economy" resulting from their high growth rate, and would, therefore, have benefited from increased dietary protein. It seems that growth velocity, as well as maturity and diet, must be considered when interpreting plasma amino acid values in an individual baby. There are two implications for the nutrition of the low birth weight baby. The higher plasma threonine concentrations found in the babies receiving the demineralized whey formula does prompt a word of caution when further increase in the whey:casein ratio is contemplated. At energy intakes around $130 \mathrm{kcal} / \mathrm{kg} /$ day, protein may become a limiting nutrient both in terms of quality and quantity. (Pediatr Res 19: 446-450, 1985)
\end{abstract}

Abbreviations

C, curd

CW, curd and whey

LGA, light for gestational age

There has been considerable recent interest in the plasma concentrations of amino acids in early life, mainly because of their important use in the diagnosis and management of inborn errors of metabolism $(1,2)$ but also because they reflect nutritional status $(3,4)$. Not only have plasma amino acid levels been

Received July 5, 1984; accepted December 31, 1984.

Supported by John Wyeth Ltd. Technical assistance of Mrs. Sylvia Milner, supported by a grant from the West Midlands Regional Health Authority is acknowledged. H.M.B. was a Sheldon and Mary Crosse Research Fellow.

Communications to Dr. P. H. Scott, Biochemistry Department, Selly Oak Hospital, Selly Oak, Birmingham B29 6JD, England.

${ }^{1}$ Present address: University Hospital, Leiden, The Netherlands. shown to be related to dietary protein quantity, but recent work has also shown a relationship with dietary protein quality $(5,6)$.

There has been no single study in which plasma amino acids have been related to the numerous factors affecting the newborn baby such as conceptional and postnatal age, growth velocity, and the absorption and retention of dietary protein. As part of a study of neonatal protein nutrition (7) we have been able to examine these factors and have shown that growth velocity in particular is a more important determinant of certain plasma amino acid levels than has been previously realized. Some of the results have appeared in a preliminary communication (8).

\section{SUBJECTS AND METHODS}

Patients. Two groups of low birth weight babies were studied.

"Preterm" group (32 babies). This group consisted of those infants of gestational age less than 37 completed wk by obstetric and pediatric assessment; birth weight (mean \pm SD) $2.07 \mathrm{~kg} \pm$ $0.16,19$ appropriate weight (10-90th centile), and 13 LGA (less than 10th percentile) from data of Gairdner and Pearson (9).

"Term LGA" group (23 babies). This group consisted of those infants of gestational age 37-41 completed wk; birth weight (mean $\pm \mathrm{SD}$ ) $2.08 \mathrm{~kg} \pm 0.15$, LGA, i.e. less than 10th percentile.

The babies were admitted to the Special Care Baby Unit of the Sorrento Maternity Hospital and entered the study if their mothers were unable to provide breast milk and had given their informed consent.

Feeding regimen. The babies were randomly allocated to receive one of the two formulas (both produced by John Wyeth Ltd.): (1) one in which the source of protein was skimmed cow's milk i.e. unmodified cow's milk protein, $82 \%$ casein (curd) protein (SMA, referred to as C formula), and (2) one in which the source of protein was predominantly demineralized whey, i.e. $40 \%$ casein: $60 \%$ whey protein (S26, referred to as $\mathrm{CW}$ formula).

Although quantitatively the protein in the two formulas was identical $(1.5 \mathrm{~g} / 100 \mathrm{~mL}, 2.25 \mathrm{~g} / 100 \mathrm{kcal})$, their amino acid compositions were not. The first 2 columns of Table 1 show the amino acid composition of the protein in the reconstituted formulas. This was determined after acid hydrolysis of the milk (during which tryptophan was totally destroyed) by the Macromolecular Analysis Service, University of Birmingham. The CW formula contained more threonine $(+20 \%)$, aspartic acid $(+13 \%)$, and alanine $(+19 \%)$, and less phenylalanine $(-13 \%)$ and histidine $(-24 \%)$. The formulas were specially supplied by the manufacturers for this study. They had an identical fat blend, containing polyunsaturated vegetable fats, as well as animal fat. At reconstitution extra sodium ( $5 \mathrm{mmol} /$ liter as citrate) and potassium ( $2 \mathrm{mmol} /$ liter as chloride and $4 \mathrm{mmol} /$ liter as citrate) were added to the $\mathrm{CW}$ formula as described elsewhere (10). This gave final concentration of $12 \mathrm{mmol} /$ liter of sodium and 20 $\mathrm{mmol} / \mathrm{liter}$ of potassium, equal to their concentration in the $\mathrm{C}$ formula. 
GROWTH VELOCITY, PLASMA AA, AND NEWBORNS

Table 1. Amino acid concentrations in the preterm and term LGA babies' plasma [Mean (SD)] and in the C and CW formulas

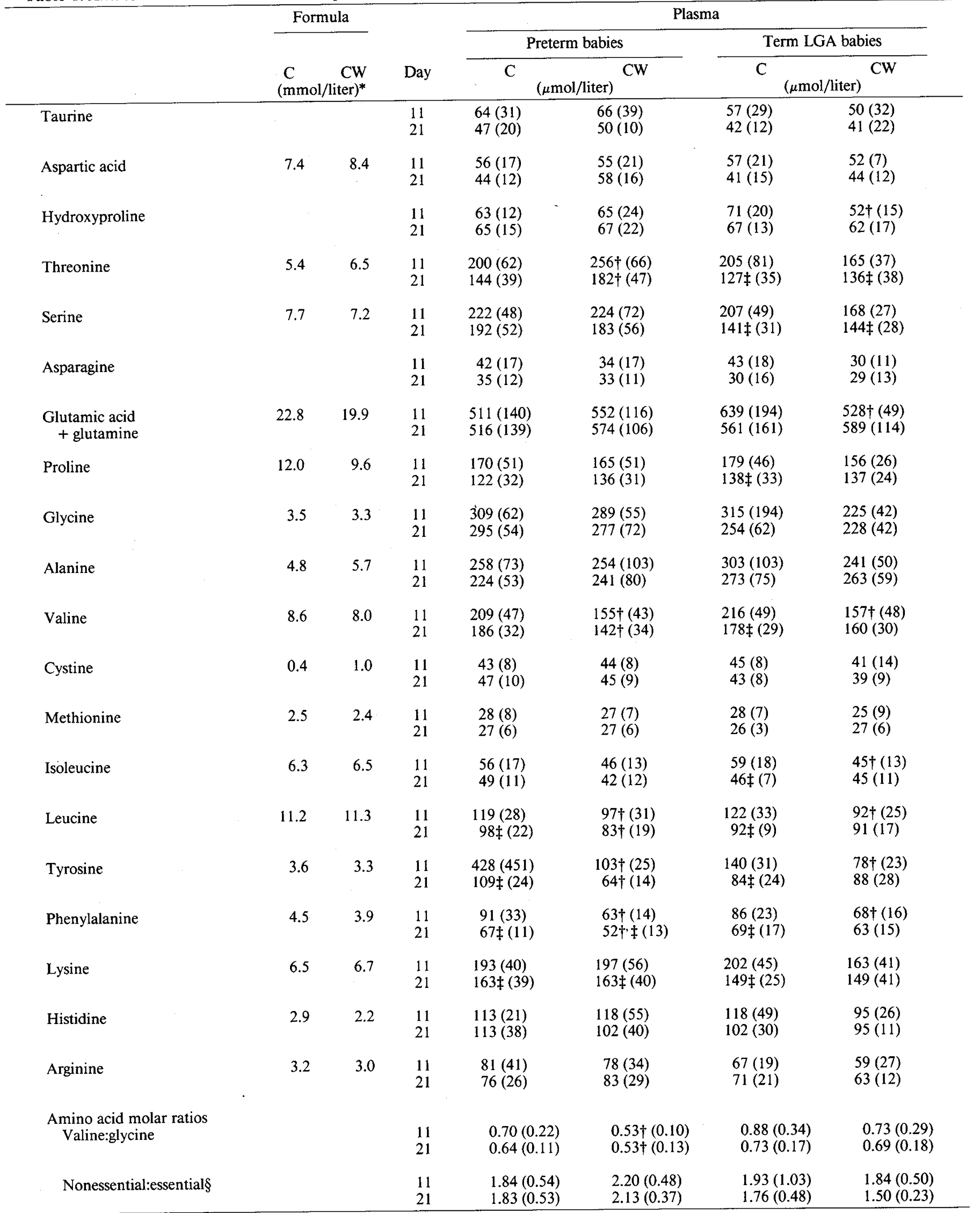

* To convert to $\mu \mathrm{mol} / 100 \mathrm{kcal}$ multiply by 150 , or to $\mu \mathrm{mol} / \mathrm{MJ}$ multiply by 358 .

+ Denotes a significant difference between $\mathrm{C}$ and $\mathrm{CW}$ groups $(p<0.05)$.

$\$$ Denotes a significant difference from day 11 to $21(p<0.05)$.

$\S$ Ratio of the sum of the concentrations of glycine, serine, glutamine, and taurine to that of isoleucine, leucine, valine, and methionine. 
The babies received their first feeds within $4 \mathrm{~h}$ of birth and were fed according to the standard feeding schedule of the unit such that by the 9th day of life all of the babies were receiving $200 \mathrm{ml} / \mathrm{kg}$ body weight per day, providing $134 \mathrm{kcal}(560 \mathrm{~kJ})$ and $3 \mathrm{~g}$ of protein ( $9 \%$ of energy).

Anthropometry. Measurements were made at birth and thereafter at weekly intervals; weight was determined with a Salter spring balance and length with a Harpenden neonatometer.

Biochemistry. Blood specimens were obtained on days 11 and $21,4 \mathrm{~h}$ after the $0600 \mathrm{~h}$ feed which was also immediately prior to the next feed. Choice of a particular time of day minimized variation due to the well documented circadian periodicity of blood amino acid concentrations (11). Before blood was collected by heel prick, the heel was swabbed with methanol. Blood was always free flowing and that for other measurements was always collected from the site first. Contamination of specimen with skin surface amino acids is minimal in the newborn (12). The blood was centrifuged immediately, and the plasma separated. Plasma protein was precipitated using sulphosalicylic acid after addition of norleucine as an internal standard. The maximum time taken from specimen collection to completion of this stage was $1 \mathrm{hr}$; it was usually considerably less. Until analysis all specimens were stored at $-20^{\circ} \mathrm{C}$. Amino acids were measured using a Locarte amino acid analyzer. The only amino acid affected by storage was glutamine which is converted to glutamic acid (13); therefore quantitatively the results were expressed as the sum of these two amino acids. Values for tryptophan, ornithine, and citrulline were either not available or incomplete and so have been excluded.

Nitrogen balances were performed on a group of 14 babies (seven on the $\mathrm{C}$ formula and seven on the $\mathrm{CW}$ formula, for 3 to 5 -day periods terminating on day 19), using a procedure similar to that of Fomon (14). Total nitrogen determinations of milk, urine, and feces were made using the method of Shahinian and Reinhold (15).

Results were analyzed for statistical significance using a paired $t$ test for differences between days 11 and 21 , and an unpaired $t$ test for differences between the preterm and term LGA dietary groups. Linear regression analysis was performed using Deming's method (16).

\section{RESULTS}

Plasma amino acid concentrations and ratios. These are shown in Table 1 and show two distinct trends: 1) amino acid levels were in general higher in babies receiving the $C$ formula than in those on the $\mathrm{CW}$ formula though threonine was an exception, and 2) irrespective of diet, amino acid levels fell from day 11 to 21 . Both these trends were more obvious in the preterm babies and affected essential rather than nonessential amino acids.

The valine:glycine ratio was lower in the preterm babies fed the $\mathrm{C}$ formula; there was no corresponding increase in the nonessential to essential amino acid ratio.

Relationships of plasma amino acid concentrations to growth and nitrogen balance. Results in Table 2 show that the babies receiving the $\mathrm{CW}$ formula grew heavier and longer (significant for preterm babies only) and absorbed a greater proportion of the dietary nitrogen than those receiving the $\mathrm{C}$ formula.

The babies growing most rapidly and with the higher nitrogen retentions had the lower concentrations of branched-chain amino acids and cystine. Higher nitrogen adsorption was associated with a higher plasma phenylalanine concentration (Table 3, Figs. 1 and 2).

\section{DISCUSSION}

Three factors appear to affect the concentrations of plasma amino acids. Of these the maturity of the infant and the quantity and quality of dietary protein are well known, but little attention has been paid to the effect of growth velocity.
Table 2. Anthropometry and nitrogen balance results [mean (SD)] in the two dietary groups

\begin{tabular}{lll}
\hline & \multicolumn{1}{c}{$\mathrm{C}$} & \multicolumn{1}{c}{$\mathrm{CW}$} \\
\hline Wt gain, day 7-21 (g/day) & $21.9(5.9)$ & $27.3(8.8)^{*}$ \\
Length increase day 7 to 21 (mm/day) & $1.12(0.41)$ & $1.42(0.29)^{*}$ \\
Nitrogen absorbed (mmol/kg/day) & $31.9(1.4)$ & $33.1(1.5)$ \\
Nitrogen absorbed as \% of intake & $90(3)$ & $93(1)^{*}$ \\
Nitrogen retained (mmol/kg/day) & $21.5(3.4)$ & $23.2(1.1)$ \\
Nitrogen retained as \% of absorption & $67(10)$ & $70(5)$ \\
\hline
\end{tabular}

* Significant difference from C group, $p<0.05$ ( $t$ test).

Table 3. Correlations of plasma amino acid concentrations (day 21) with growth and nitrogen balance

\begin{tabular}{lcc}
\hline & $r$ & $p$ \\
\hline Valine with & -0.35 & $<0.01$ \\
Wt gain (day 7-21) & -0.43 & $<0.001$ \\
Length increase (day 7-21) & -0.57 & $<0.05$ \\
Nitrogen retention & -0.59 & $<0.05$ \\
Nitrogen retention as \% absorption & & \\
& & \\
Leucine with & -0.32 & $<0.02$ \\
Length increase (day 7-21) & -0.53 & $<0.05$ \\
Nitrogen retention & -0.55 & $<0.05$ \\
$\quad$ Nitrogen retention as \% absorption & & \\
& & \\
Isoleucine with & -0.37 & $=0.005$ \\
Length increase (day 7-21) & -0.55 & $<0.05$ \\
Nitrogen retention as \% absorption & & \\
& & \\
Cystine with & -0.37 & $=0.005$ \\
Length increase (day 7-21) & -0.65 & $<0.05$ \\
Nitrogen retention & -0.65 & $<0.05$ \\
Nitrogen retention as \% absorption & & \\
& & \\
Phenylalanine with & 0.59 & $<0.05$ \\
\hline Nitrogen absorption as \% intake & & \\
\hline
\end{tabular}

Maturity of the infant. Plasma amino acid concentrations, particularly threonine and serine, the branched-chain amino acids, tyrosine, phenylalanine, and lysine, fell over the period of study from initially high levels. This trend probably reflected a maturation of amino acid metabolism in the newborn low birth weight baby (17-19). Plasma levels of serine and tyrosine were higher in the preterm babies than in the term LGA ones. Morris et al. (20), analyzing screening program results, noted the increased frequency of plasma tyrosine values greater than 450 $\mu \mathrm{mol} / \mathrm{liter}$ in infants who were less than $2 \mathrm{~kg}$ at birth, particularly those who were preterm. Apart from valine, leucine, and isoleucine, the plasma amino acid concentrations did not correlate with growth so that maturity rather than growth was probably the primary factor influencing their levels.

Rigo and Senterre (21) have recently shown (21), only in infants receiving a relatively high threonine intake, that preterm infants had higher plasma levels of the amino acid than term infants. Jarvenpää et al. (22), using a lower threonine intake in term babies, demonstrated a higher plasma threonine in infants receiving a $\mathrm{CW}$ formula compared with infants receiving a predominantly $\mathrm{C}$ formula or breast milk. They later reported (23) no correlation with gestational age in infants receiving high threonine intakes.

Our findings in preterm and term LGA babies receiving comparatively low threonine intakes extend these observations. The higher plasma threonine levels were seen in those preterm babies who received the $\mathrm{CW}$ formula and, therefore, a higher threonine intake. This persisted to the 21 st day of life. It could be concluded, therefore, that the trend indicates some metabolic im- 
maturity in the handling of threonine. An equivalent group of term LGA babies did not show this but demonstrated a greater fall in plasma levels from day 11 to 21 . This could further indicate that even these term babies matured in their handling of threonine over the first weeks of life.

Dietary protein. Differences in the plasma amino acids are in some instances explained by differences in the composition of the dietary protein. The $\mathrm{CW}$ formula had less phenylalanine and
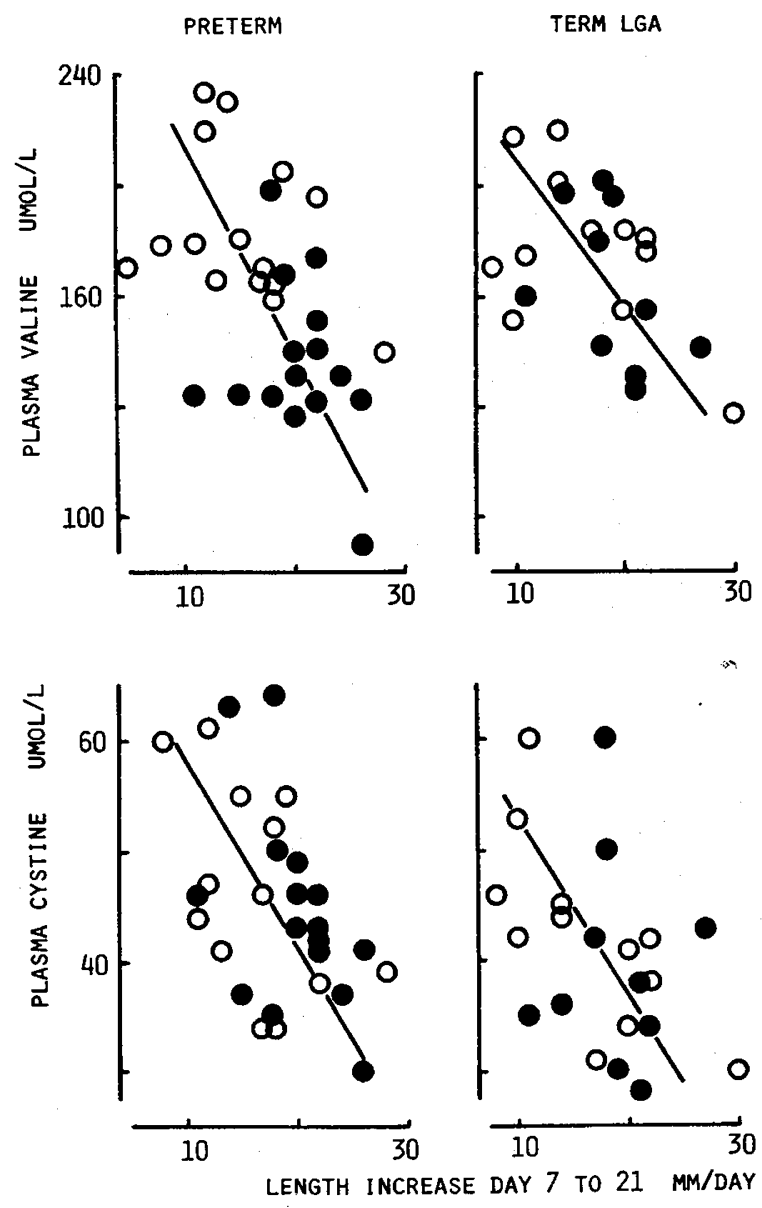

Fig. 1. Correlations of length increase with $(a)$ plasma valine in preterm $(r=-0.48, p<0.01)$ and term LGA $(r=-0.51, p<0.02)$ babies and $(b)$ plasma cystine in preterm $(r=-0.36, p=0.05)$ and term LGA $(r=-0.44, p<0.05)$ babies fed $\mathrm{C}(\mathrm{O})$ and $\mathrm{CW}(\bullet)$ formulas. more threonine and plasma levels reflect this. Plasma phenylalanine correlated with absorption of nitrogen from ingested protein. These dietary differences, however, cannot explain other observations. While the babies fed the CW formula had lower plasma levels of tyrosine and branched-chain amino acids, their intakes of these amino acids were little different from those of babies fed the $\mathrm{C}$ formula. While higher protein intakes have been associated with increases in plasma amino acids, such as phenylalanine and tyrosine (24), our observations suggest that protein quality may influence plasma amino acid levels in a way distinct from that of protein quantity.

Growth rate, protein, and energy intake. Low plasma concentrations of branch-chain amino acids and a low valine:glycine ratio have been observed in malnutrition and have been used as a biochemical sign of undernutrition (25). In this study, a low concentration of circulating branched-chain amino acids was associated with rapid growth and greater retention of nitrogenhardly signs of poor nutrition. We have previously shown that a raised plasma alkaline ribonuclease activity, also a common sign of poor protein nutrition $(26,27)$, was similarly associated with rapid growth in low birth weight babies (28). We suggest that the lower plasma concentrations of valine leucine, and isoleucine, similar to the elevated alkaline ribonuclease activity, are biochemical signs of "protein economy" caused by rapid growth.

In a similar study Rassin et al. (6) used a formula with a lower protein:energy ratio than ours (1.9 compared to $2.25 \mathrm{~g}$ protein per $100 \mathrm{kcal}$ ) and their babies received a lower total energy intake (117 compared with $134 \mathrm{kcal} / \mathrm{kg} /$ day). They reported higher concentrations of branched-chain amino acids during the 3rd wk of life than those reported herein and no significant differences between $\mathrm{CW}$ fed groups. Correlations with growth velocity were not given. Jonxis (29) showed that increasing the energy intake without increasing that of the protein in premature babies resulted in increased growth and lower plasma branched-chain amino acids. It is, therefore, likely that at modest intakes of energy and protein, as used by Rassin et al. (6) energy intake was growth limiting, and so differences in dietary protein quality had no effect on either growth velocity or branched-chain amino acid levels. At higher protein and energy intakes, such as we used, growth is not limited by available energy so that the effects reported herein become apparent. There is, therefore, an interrelationship among energy intake, protein intake, growth velocity, and plasma branched-chain amino acid levels which must not be overlooked.

Plasma cystine was similarly inversely related to growth; those babies who grew faster had lower plasma levels of the amino acid. Cystine has been taken to be an essential amino acid in the newborn due to the immaturity of the liver enzymes of the transulfuration pathway $(18,19)$. However, recent evidence (30)
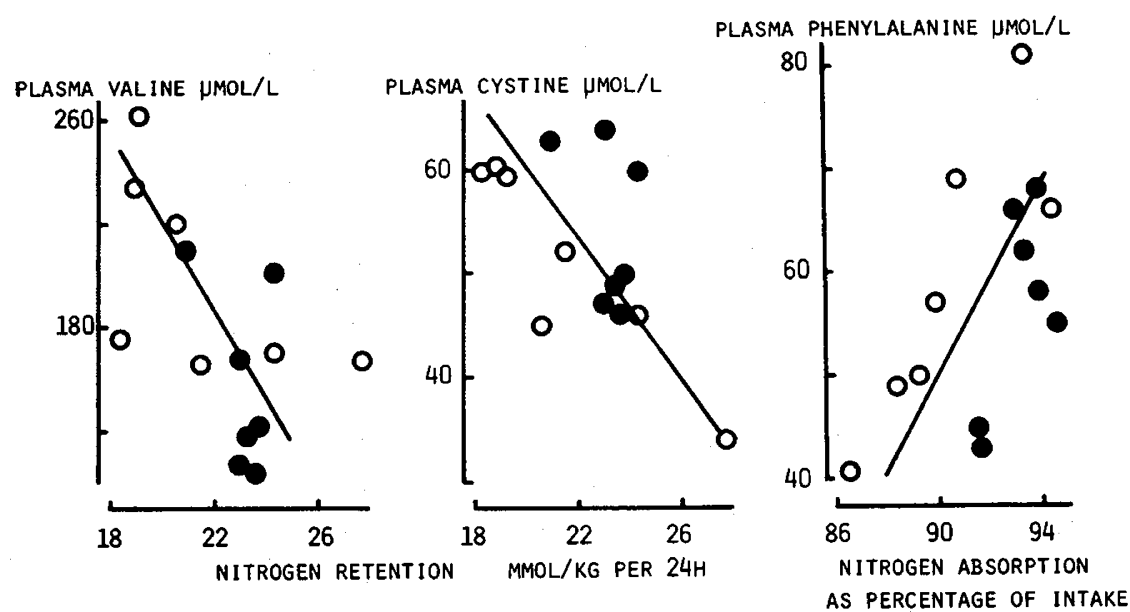

Fig. 2. Correlations of nitrogen retention with plasma valine $(r=-0.57, p<0.05)$ and plasma cystine $(r=-0.65, p<0.05)$ and of nitrogen absorption as a percentage of intake with plasma phenylalanine $(r=0.59, p<0.05)$ in low birth weight babies fed $\mathrm{C}(\mathrm{O})$ and $\mathrm{CW}(\bullet)$ formulas. 
suggests that the kidney and adrenal tissues of the preterm infant contain significant cystathionase activity. Therefore, the dietary requirement for cystine continues to be debated. Results from this study suggest that during a period of high catch-up growth cystine may be depleted and could become a limiting nutrient for growth. We are studying this possibility in more detail.

Clinical implications. Clearly the interpretation of an individual plasma amino acid concentration must be related to the age of the subject-a well known principle of pediatric chemical pathology. The effect of interpretation in relation to diet is less well established. Following the publication of Present day Practice in Infant Feeding (31) and the ESPGAN Guidelines on Infant Nutrition (32), most babies in Europe now receive a diet much lower in protein quantity than previously (more babies are breastfed and the remainder receive an infant formula rather than cows' milk) and many receive substantial amounts of whey protein (33) (either breast milk or a formula based on demineralized whey, such as that used in this study). Reference ranges previously established in babies receiving whole cows' milk are, therefore, quite inappropriate and may lead to the delayed diagnosis of an inborn error of metabolism in a baby receiving a lower protein, higher whey content food, such as breast milk (20).

The higher intake and plasma concentration of threonine associated with the CW formula fed babies cautions the use of larger amounts of whey protein than those used in this study $(60 \%$ of $3 \mathrm{~g} / \mathrm{kg}$ or $60 \%$ of $2.25 \mathrm{~g} / 100 \mathrm{kcal})$ without a careful biochemical assessment.

Interpretation of amino acid data in relation to growth velocity and energy intake has received little attention. Isolated biochemical interpretation could have led, on the basis of reduced branchchain amino acids and reduced valine:glycine ratio, to a diagnosis of malnutrition, yet the babies were growing rapidly. In general one should be wary of a nutritional interpretation of a biochemical finding unless there is accompanying anthropometric and/ or clinical evidence. At the same time it seems probable that the lower branched-chain amino acids in particular, and possibly the lower cystine concentrations, in rapidly growing babies were an indication of protein economy and suggest that these babies would have benefited from a greater intake of protein. There is also some indication that at energy intakes below $130 \mathrm{kcal} / \mathrm{kg} /$ day, protein may become a limiting nutrient.

\section{REFERENCES}

1. Scriver CR, Rosenberg LE 1973 Amino Acid Metabolism and Its Disorders. Saunders, Philadelphia, pp 345-348

2. Snyderman SE 1971 Diagnosis of Metabolic Disease. Pediatr Clin North Am 18:199-208

3. Snyderman SE, Holt LE, Norton PM, Roitman E, Phansalkar SV 1968 The plasma aminogram $I$. Influence of the level of protein intake and a comparison of whole protein and amino acid diets. Pediatr Res 2:131-144

4. Whitehead RG 1967 Biochemical tests in differential diagnosis of protein and calorie deficiencies. Arch Dis Child 42:479-484

5. Räihä NCR, Heinonen K, Rassin DK, Gaull GE 1976 Milk protein quantity and quality in low-birth-weight infants: I Metabolic responses and effects on growth. Pediatrics 57:659-674

6. Rassin DK, Gaull GE, Heinonen K, Räihä NCR 1977 Milk protein quantity and quality in low-birth-weight infants: II Effects on selected aliphatic aminoacids in plasma and urine. Pediatrics 59:407-422
7. Berger HM, Scott PH, Kenward C, Scott P, Wharton BA 1979 Curd and whey proteins in the nutrition of low birthweight babies. Arch Dis Child 54:98104

8. Scott PH, Berger HM, Wharton BA 1981 The effect of protein quality on plasma aminoacid levels in low birthweight babies. In: Rattenbury JM (ed) Amino Acid Analysis. Ellis Horwood, Chichester, pp 188-194

9. Gairdner D, Pearson J 1971 A growth chart for premature and other infants. Arch Dis Child 46:783-787

10. Berger HM, Scott PH, Kenward C, Scott P, Wharton BA 1978 Milk pH, acid base status, and growth in babies. Arch Dis Child 53:926-930

11. Feigin RD, Haymond MW 1970 Circadian periodicity of blood amino acids in the neonate. Pediatrics 45:782-791

12. Stegink LD, Filer LJ, Baker GL 1982 Effect of sampling site on plasma amino acid concentrations of infants: effects of skin aminoacids. Am J Clin Nutr $36: 917-925$

13. Perry TL, Hansen S 1969 Technical pitfalls leading to errors in the quantitation of plasma amino acids. Clin Chim Acta 25:53-58

14. Fomon SJ 1974 Infant Nutrition. Saunders, Philadelphia

15. Shahinian AH, Reinhold JG 1971 Application of the phenol-hypochlorite reaction to measurement of ammonia concentration in Kjeldhal digests of serum and various tissues. Clin Chem 17:1077-1082

16. Cornbleet PJ, Gochman N 1979 Incorrect least-squares regression coefficients in method-comparison analysis. Clin Chem 25:432-438

17. Abitbol CL, Feldman DB, Ahmann P, Rudman D 1975 Plasma aminoacid patterns during supplemental nutrition of low birthweight infants. J Pediatr $86: 766-772$

18. Gaull G, Sturman JA, Räihä NCR 1972 Development of mammalian sulfur metabolism: absence of cystathionase in human fetal tissues. Pediatr Res 6:538-547

19. Sturman JA, Rassin DK, Gaull GE 1977 Taurine in development. Life Sci $21: 1-21$

20. Morris AF, Holton JB, Burman D, Colley JRT 1983 Phenylalanine and tyrosine levels in newborn screening blood samples. Arch Dis Child 58:271275

21. Rigo J, Senterre J 1980 Optimal threonine intake for preterm infants fed on oral or parenteral nutrition. JPEN 4:15-17

22. Jarvenpää A-L, Rassin DK, Räihä NCR 1982 Milk protein quantity and quality in the term infant: II Effects on acidic and neutral aminoacids. Pediatrics 70:221-230

23. Räihä N, Rassin D, Gaull G 1983 Plasma threonine in premature infants. Pediatrics 72:143-144

24. Przyrembel H, Leupold D, Tosberg P 1973 Amino acid excretion of premature infants receiving different amounts of protein. Clin Chim Acta 49:27-39

25. Lindblad BS, Rahimtoola RJ, Said M, Haque Q, Khan N 1969 The venous plasma free aminoacid level of mother and child during delivery: III In a lower socio-economic group of a refugee area in Karachi, West Pakistan, with special reference to the 'small for dates' syndrome. Acta Paed Scand 58:497-505

26. Sigulem DM, Brasel JA, Valesco EG, Rosso P, Winick M 1973 Plasma and urine ribonuclease as a measure of nutritional status in children. Am J Clin Nutr 26:793-797

27. Scott PH, Berger HM, Wharton BA 1984 A critical assessment of plasma alkaline ribonuclease as an indicator of protein nutritional status in infancy. Ann Clin Biochem 21:357-362

28. Scott PH, Berger HM, Kenward C, Scott P, Wharton BA 1978 Plasma alkaline ribonuclease (EC 3.1.4.22) and nitrogen retention in low-birth-weight infants. Br J Nutr 40:459-464

29. Jonxis JHP 1976 Special problems arising in the nutrition of very smal prematures and their subsequent growth. In: Wilkinson AW (ed) Early Nutrition and Later Development. Pitman Medical, London, pp 79-91

30. Zlotkin SH, Anderson GH 1982 The development of cystathionase activity during the first year of life. Pediatr Res 16:65-68

31. Oppe TE, Arneil GC, Creery RDG, Lloyd JK, Stroud CE, Wharton BA Widdowson EM 1974 Present day practice in infant feeding. In: Report on Health and Social Subjects. HMSO, London

32. ESPGAN Committee on Nutrition 1977 Guidelines on infant nutrition 1. Recommendations for the composition of an adapted formula. Acta Paediat Scand Suppl 262:5-8

33. Wharton BA 1980 Past achievements and future priorities: a view of present day practice in infant feeding. In: Turner MR (ed) Nutrition and Health: A Perspective. MTP Press, Lancaster, pp 169-181 